\title{
A Europe à deux vitesses for Enterprise Taxation?
}

\author{
Otmar Thoemmes, Deloitte Touche Tohmatsu, Munich
}

Enterprise taxation in Europe seems to be the sole remaining area that is resisting alignment of the Internal Market. In a desperate attempt to retain fiscal sovereignty, Member States cling to their national tax regimes at the expense of European enterprises that must contend with a multitude of tax laws and the diverse implications of their application in practice.

Although the EC Treaty has undergone a series of far-reaching renovations since its entry into force, the strict unanimity requirement in tax matters has survived all attempts to replace it with qualified majority decision making.

Is unanimous consensus on tax matters possible in a Europe of 25 Member States? The answer is clearly, no. The first reason for this pessimistic outlook is the Member States' perception that majority decision making in tax harmonization matters could deprive them of their fiscal sovereignty. To some extent, this fear has a real basis, but it is also true that advanced tax harmonization would most benefit those Member States that are the fiercest opponents of majority decision making.

Next, secondary Community law not only requires unanimity to become adopted, but it also requires unanimity to be subsequently amended, if necessary. Once adopted, secondary EC law on tax matters is as difficult to amend as it was to adopt in the first instance. This 'dead-end' phenomenon precludes any flexibility in adopting a 'trial and error' approach to EC law measures.

Unanimity among twelve Member States, while fraught with challenges, was achievable as is demonstrated by the two 1990 tax Directives. Unanimity among 25 Member States, however, seems out of the question.

The ECJ's strict interpretation of directly applicable primary EC law in tax matters has sent powerful shock waves throughout the EU. Ignoring the fact that national government resistance to tax harmonization has been the impetus for the ECJ to break new ground for the fundamental European freedoms, governments have shifted blame onto the Court and have begun to devise ways to restrict the competency of the ECJ and the impact of European law on their national tax systems. While the risk that Member States actually embark on a journey to restrict ECJ competence is limited, at the same time, Member States are not particularly keen to move to a true internal market for enterprise taxation. Yet, not taking any action is likely to result in the ECJ's role becoming even more prominent with respect to company tax harmonization, and a potential for the ECJ to make further 'intrusions' on national fiscal policy. There may be a middle ground, however.

Following its reform by the Treaty of Amsterdam, and as amended by the Treaty of Nice, the European legal order provides for an instrument that could break the deadlock caused by the unanimity requirement, strengthening the position of Member States willing to cooperate and weakening the position of those reluctant to do so. The 'Enhanced Cooperation' mechanism would allow Member States to take action even though not all Member States participate. Under this alternative measure, a minimum of eight Member States may receive permission to utilize procedures authorized by the EC Treaty, and any decisions reached by such Member States would apply only to them. The Enhanced Cooperation mechanism is effectively a 'coalition of the willing'. Member States unwilling to cooperate and unable to control the process of tax harmonization by threatening partners with their right of veto, would be required either to refrain from participating or opt in.

The advantages of this alternative approach are readily apparent in the context of the development of the EC Arbitration Convention. The prolongation of the Convention was due in 2000 and required the unanimous ratification of a protocol signed in 1999 amending the Arbitration Convention. The last Member State (i.e. Portugal) did not ratify the prolongation protocol until 2004, delaying the entry into force of the entire Convention for four years. In contrast to the prolongation protocol, the accession of the '1995' Accession States (i.e. Austria, Finland and Sweden) did not require unanimity in ratifying an Accession Convention so the Convention at least became applicable between the Member States that ratified it. With respect to the ten newest Member States, the Accession Convention to the Arbitration Convention could work, according to the Joint Transfer Pricing Forum (in its recent proposal for a Code of Conduct for the effective implementation of the Arbitration Convention) in a way that allows a gradual extension of the Convention's personal scope to include new Member States that have signed the Convention and completed the requisite ratification procedures.

Obviously, this gradual approach is not appropriate or effective for all matters of taxation. The most recent discussions regarding the EC Savings Directive demonstrate that closing tax loopholes in the taxation of 
income from savings requires a fully integrated approach that does not allow for exceptions. Otherwise, the pressure on taxpayers from countries that have agreed to more restrictive rules would operate to benefit those that do not agree to close their loopholes. A fragmented approach would create the opposite of what was envisaged and intended.

While the taxation of income from savings is an extreme example of a measure for which a gradual approach does not work, similar problems are likely to arise if the Member States tried to adopt minimum tax rates but a limited number of jurisdictions were to refrain from an agreement. The closing of loopholes and the introduction of minimum tax rates, however, are not the only features of tax harmonization, nor are they the most urgently needed measures.

It is one of the obscure anomalies in the development of tax harmonization measures that, for some reason, tax rates were thought to require priority in the efforts to align more closely Member States' tax laws. From the perspective of an enterprise, however, the opposite is true. Common rules on the determination of profits, including rules regarding the allocation of profits within European groups of companies, are by far more pressing issues. It is precisely in this area where a gradual approach of Enhanced Cooperation could pave the way for meaningful progress. The initiative launched by Internal Market Commissioner, Frits Bolkestein, on 7 July 2004 regarding a 'common consolidated tax base' deserves diligent attention and support.
If ultimately not all 25 Member States agree to a common set of rules for the determination of enterprise profits (or at least certain key features of profit determination), those that are in agreement could launch a limited scope pilot project under the Enhanced Cooperation mechanism. Article 11 of the EC Treaty, in conjunction with Art. 43 et seq., could form the legal basis of such a project, provided at least eight Member States participate in the initiative. The proven benefits of a successful implementation of an enhanced cooperation initiative would soon convince the more tentative Member States of the merits of Enhanced Cooperation. The corresponding reduction in the administrative burden that results from the multiplicity of rules would allow enterprises (and their respective Member States) that would be entitled to the benefits of the aligned rules to flourish and gain a competitive advantage. Once convinced by the success of the front-runners, hesitant Member States could decide to opt in at a later stage and also enjoy the benefits of the uniform rule upon signing the extension instrument and implementing it into national law. There is no compelling reason why this approach, if it works for the procedural rules of the Arbitration Convention, should not work for substantive rules on profit determination and their cross-boarder ramifications. It is worth a try, and far better than languishing in the landscape of the discouraging effects of strict unanimity. 